\title{
Inhibiting PKC $\beta 2$ protects HK-2 cells against meglumine diatrizoate and AGEs-induced apoptosis and autophagy
}

\author{
Wenbing Jiang ${ }^{1}$, Wei Zhao ${ }^{1}$, Fanhao Ye ${ }^{1}$, Shiwei Huang ${ }^{1}$, Youyang Wu ${ }^{1}$, Hao Chen ${ }^{1}$, Rui Zhou ${ }^{1}$, Guosheng Fu ${ }^{2}$ \\ ${ }^{1}$ Department of Cardiology, The Third Clinical Institute Affiliated to Wenzhou Medical University, Wenzhou 325000, China; ${ }^{2}$ Department of \\ Cardiology, Sir Run Run Shaw Hospital, College of Medicine, Zhejiang University, Hangzhou 310016, China \\ Contributions: (I) Conception and design: G Fu; (II) Administrative support: None; (III) Provision of study materials or patients: None; (IV) \\ Collection and assembly of data: S Huang, Y Wu, H Chen, R Zhou; (V) Data analysis and interpretation: W Jiang, W Zhao, F Ye; (VI) Manuscript \\ writing: All authors; (VII) Final approval of manuscript: All authors. \\ Correspondence to: Guosheng Fu. Department of Cardiology, Sir Run Run Shaw Hospital, College of Medicine, Zhejiang University, No. 3 East \\ Qingchun Road, Hangzhou 310016, China. Email: fugsmedmail@163.com.
}

Background: Contrast induced diabetic nephropathy (CIN) is an important cause of hospital-acquired acute renal failure. Our aim was to observe the effect of protein kinase C $\beta 2$ (PKC $\beta 2$ ) knockdown on human proximal tubular epithelial cells (HK-2 cells) against meglumine diatrizoate and advanced glycation end products (AGEs)-induced apoptosis and autophagy.

Methods: Cell viability was detected using cell counting kit-8 (CCK-8) assay in HK-2 cells after disposal with meglumine diatrizoate and AGEs with or without PKC $\beta 2$ siRNA/inhibitor LY333531. Flow cytometry and western blot were used to test cell apoptosis and the related protein levels in meglumine diatrizoate and AGEs co-treated HK-2 cells with or without PKCß2 siRNA/inhibitor LY333531. Autophagy related proteins were detected using western blot. Immunofluorescence staining was used to examine the autophagyspecific protein light chain 3 (LC3), and autophagosome and autolysosome formation was observed under a transmission electron microscopy.

Results: CCK-8 assay results showed that meglumine diatrizoate inhibited AGEs-induced HK-2 cell viability. Furthermore, meglumine diatrizoate promoted cell apoptosis and the expression level of caspase 3 in AGEs-induced HK-2. Western blot results showed that meglumine diatrizoate elevated the expression levels of PKC $\beta 2$ and p-PKC $\beta 2$ in AGEs-induced HK-2 cells, and up-regulated the expression level of Beclin-1 and the ratio of LC3 II/LC3 I, and down-regulated the expression level of p62 in AGEs-induced HK-2 cells. We found that PKC 32 knockdown alleviated meglumine diatrizoate and AGEs-induced HK-2 cell apoptosis and autophagy. Intriguingly, PKCß2 inhibitor LY333531 reversed 3-methyladenine (3-MA)-induced autophagy inhibition in meglumine diatrizoate and AGEs-induced HK-2 cells.

Conclusions: Our findings reveal that inhibiting PKC $\beta 2$ protects HK-2 cells against meglumine diatrizoate and AGEs-induced apoptosis and autophagy, which provide a novel therapeutic insight for CIN in diabetic patients.

Keywords: Contrast induced diabetic nephropathy (CIN); advanced glycation end products advanced glycation end products (AGEs); protein kinase C $\beta 2$ (PKC $\beta 2$ ); meglumine diatrizoate; HK-2 cells

Submitted Dec 03, 2019. Accepted for publication Feb 04, 2020.

doi: $10.21037 /$ atm.2020.02.172

View this article at: http://dx.doi.org/10.21037/atm.2020.02.172 


\section{Introduction}

CIN is the third cause of hospital-acquired acute kidney injury (1). In patients undergoing coronary angiography or percutaneous coronary intervention, the incidence of CIN is as high as $20 \%$ to $25 \%$ (1). CIN is usually defined as an absolute increase of $0.5 \mathrm{mg} / \mathrm{dL}$ or a relative increase of $25 \%$ in serum creatinine within $48-72$ hours after contrast exposure (2). But it is recommended that CIN should be also considered in the presence of acute renal failure within 7 days of exposure (3). However, in high-risk populations, such as diabetics, the incidence increases to $50 \%(4,5)$. Diabetes is an independent risk factor for CIN. For every baseline glomerular filtration rate in patients with chronic kidney disease, the presence of diabetes doubles the risk of developing CIN $(6,7)$. Therefore, there is an urgent need to understand the mechanisms of CIN and develop effective treatment strategies.

As critical biological processes, apoptosis and autophagy are involved in regulating the pathogenesis of diabetic nephropathy (8-10). Apoptosis plays an important role in the induction of progressive loss of renal cells, leading to glomerular sclerosis, tubular atrophy and renal interstitial fibrosis (11). Bcl-2, an apoptosis-related protein, may mediate cell apoptosis via activation of its downstream pathways (12). Caspase-3, a member of Caspase family, can regulate cell apoptosis process (13). Autophagy participates in maintaining the stable structure and function of proximal tubular epithelial cells (14). As a common autophagosome marker protein in mammalian cells, it has been confirmed that LC3 is involved in the formation of autophagy (15). Beclin-1, a homologous gene of yeast autophagy gene Atg6/ Vps30, is a key molecule in the formation of autophagosome (15).

AGEs are harmful protein products that are highly expressed in patients with kidney diseases (16). Furthermore, AGEs are the major cause of diabetic microvascular lesions. Persistent AGE exposure usually leads to damage to renal tubular epithelial cells (17). Our previous study found high PKC $\beta 2$ expression in CIN diabetic mice, indicating that PKC 32 could be involved in the pathogenesis of diabetic CIN (18). In this study, we found that silencing PKC $\beta 2$ mitigated meglumine diatrizoate and AGEs-induced HK-2 cell apoptosis and autophagy. These findings provided a novel insight that PKC $\beta 2$ might become a novel agent for $\mathrm{CIN}$ in diabetic patients.

\section{Methods}

\section{Cell culture}

The human kidney cell line (HK-2), an immortalized proximal tubular epithelial cell line from normal adult human kidney, was purchased from the Cell Bank of the Chinese Academy of Sciences (Shanghai, China) (19). All cells were cultured in Dulbecco's modified Eagle's medium (PM150410; Procell, Hubei, China) plus $10 \%$ fetal bovine serum (SH30084.03; Hyclone, USA), $100 \mathrm{U} / \mathrm{mL}$ penicillin and $100 \mathrm{U} / \mathrm{mL}$ streptomycin, at $37^{\circ} \mathrm{C}$ in a $5 \% \mathrm{CO}_{2}$ atmosphere.

\section{CCK-8 assay}

HK-2 cells were seeded onto 96-well plates (5,000 cells/well) for $24 \mathrm{~h}$. Afterwards, the cells were incubated with different conditions for $0,12,24,48$ and $72 \mathrm{~h}$. The cell viability was detected using the CCK-8 detection kit (CK04; DOJINDO, Shanghai, China) according to the manufacturer's instruction. Briefly, after treatment, $10 \mu \mathrm{L}$ CCK- 8 solution was added into each well and incubated for $4 \mathrm{~h}$ at $37^{\circ} \mathrm{C}$. The optical density was measured at a wavelength of $450 \mathrm{~nm}$ using a microplate reader (Biotech, USA).

\section{Apoptosis assay}

Cell apoptosis was detected using apoptosis detection kit (A211-02; Vazyme, Nanjing, China). Briefly, HK-2 cells were seeded onto 6 -well plates $\left(1.5 \times 10^{5}\right.$ cells/well $)$ for $24 \mathrm{~h}$. After $48 \mathrm{~h}$ of treatment, cells were collected and centrifugated for $5 \mathrm{~min}$. After washing with PBS (C10010500BT; Life, USA), cells were re-suspended in $100 \mu \mathrm{L}$ Annevix Binding Buffer (10x) followed by $5 \mu \mathrm{L}$ Annevix FITC and incubation for $10 \mathrm{~min}$ at room temperature in the dark. Afterwards, $5 \mu \mathrm{L}$ PI dye solution was added into the cells and incubated for $10 \mathrm{~min}$ at room temperature in the dark. Apoptotic cells were detected by flow cytometry (CytoFLEX S; Beckman, USA).

\section{RNA extraction and Real-time quantitative polymerase chain reaction ( $R T-q P C R)$}

Total RNA was extracted from HK-2 cells using TaKaRa MiniBEST Universal RNA Extraction Kit (9767; Takara, Japan). Then, RNA was reverse transcribed into cDNA. 
Table 1 The primer information for RT-qPCR

\begin{tabular}{lll}
\hline $\begin{array}{l}\text { Gene } \\
\text { name }\end{array}$ & 5'-3' sequence & Size \\
\hline GAPDH & $\begin{array}{l}\text { 5'-TCAAGAAGGTGGTGAAGCAGG-3' } \\
\text { (forward) }\end{array}$ & $115 \mathrm{bp}$ \\
& $\begin{array}{l}\text { 5'-TCAAAGGTGGAGGAGTGGGT-3' } \\
\text { (reverse) }\end{array}$ \\
PKC 32 & 5'-CATCAAATGCTCCCTCAA-3' (forward) & $187 \mathrm{bp}$ \\
& 5'-CTTAAACCAGCCATCAACA-3' (reverse) \\
KIM-1 & 5'-AATCTATGCTGGAGTCTGT-3' (forward) & $124 \mathrm{bp}$ \\
& 5'-TTGAAGGCTGCTAAATGA-3' (reverse) \\
NGAL & 5'-TCACCTCCGTCCTGTTTA-3' (forward) & $233 \mathrm{bp}$ \\
& 5'-CTCCTTGGTTCTCCCGTA-3' (reverse) \\
\hline
\end{tabular}

The expression of mRNA was detected by RT-qPCR with light cycler 480 SYBR Green I Master (Roche, Shanghai, China) and real-time quantitative PCR detection system (BioRad, USA). The primers of target genes are listed in Table 1. GAPDH was used as an internal control. The relative expression levels were calculated using the $2^{-\Delta \Delta C T}$ method.

\section{Western blot}

HK-2 cells were lysed using RIPA lysis buffer (P0013B; Beyotime, Shanghai, China) on the ice for $30 \mathrm{~min}$. After that, the protein concentration was detected using BCA protein quantitative detection kit (P0009; Beyotime, Shanghai, China). After separation in 10\% SDS-PAGE, the protein samples were transferred to polyvinylidene fluoride (PVDF) membranes. Then, the transferred membrane was blocked using $5 \%$ milk for $1 \mathrm{~h}$. After that, the membrane was incubated with primary antibodies at $4{ }^{\circ} \mathrm{C}$, followed by HRP-conjugated secondary antibodies (1:5,000; SA00001; Proteintech, Hubei, China) at room temperature for $1 \mathrm{~h}$. The primary antibodies were as follows: anti-Bcl2 (1:1,000; AF6139; Affinnity); anti-Bax (1:1,000; AF0120; Affinnity); anti-Caspase3 (1:1,000; ab32351; abcam); anti-Beclin-1 (1:1,000; 11306-1-AP; Proteintech); anti-LC3 (1:1,000; 14600-1-AP; Proteintech); anti-P62 (1:1,000; ab109012; Abcam); anti-p-PKC $\beta 2$ (1:1,000; 9375T; CST); anti-PKC $\beta 2$ (1:1,000; ab32026; Abcam); anti-p-ERK (1:2,000; 4370T; CST); anti-ERK (1:1,000; 11257-1-AP; proteintech); p-JNK (1:1,000; ab215208; Abcam); anti-JNK (1:1,000; ab179461; Abcam); anti-p-p38 (1:1,000; ab178867; Abcam); anti-p38 (1:1,000; ab170099; Abcam); anti-GAPDH $(1: 5,000)$. GAPDH served as an internal control. The protein bots were visualized using ECL (Beyotime).

\section{Immunofluorescence staining}

HK-2 cells were seeded onto $24-$ well plates $\left(7 \times 10^{4}\right.$ cells/ well) and fixed with 4\% paraformaldehyde (E672002; Sangon Biotech, Shanghai, China). After permeabilization with $0.5 \%$ Triton $\mathrm{X}-100$ for $10 \mathrm{~min}$, the cells were incubated with a blocking buffer plus 5\% BSA (V900933; sigma, USA) for $30 \mathrm{~min}$ at room temperature. The cells were incubated with LC3-green fluorescence protein (GFP) using Lipofectamine ${ }^{\mathrm{TM}} 2000$, followed by fluorescently labeled secondary antibodies (Alexa Fluor 488; Proteintech, Hubei, China) for $1 \mathrm{~h}$ at room temperature in the dark. Then, the cells were incubated with DAPI (D9542; sigma, USA) for $5 \mathrm{~min}$ in the dark. The autophagy-specific protein LC3 was observed under fluorescence confocal microscopy (UltraVIEW VoX \& IX81; Olympus, Japan).

\section{Transmission electron microscopy (TEM)}

HK-2 cells were cultured in a 6-well plate $\left(1.5 \times 10^{5}\right.$ cells/ well) for $24 \mathrm{~h}$. After $48 \mathrm{~h}$ of treatment, the cells were harvested. Followed by washing once with PBS, $1 \mathrm{~mL}$ of electron microscopy fixative was added into each well. The cells were scraped in one direction with a cell scraper and placed in a $1.5 \mathrm{~mL}$ EP tube. After that, the sample was dropped on a carbon support membrane copper mesh for 3-5 min, and then excess liquid was removed by filter paper. $2 \%$ phosphotungstic acid (Servicebio, HuBei, China) was dropped on a carbon support membrane copper mesh for 2-3 min, and excess liquid was removed by filter paper. Autophagosome and autolysosome formation were observed under a TEM (HT7700; HITACHI, Japan).

\section{Statistical analysis}

Statistical analysis was performed using GraphPad Prism 7.0. All experiments were repeated at least three times. All the data are expressed as mean \pm standard deviation (SD). Comparisons between two groups were analyzed using the Student's $t$ test. For pairwise multiple comparisons, one-way ANOVA test followed by Bonferroni posttest was performed. $\mathrm{P}<0.05$ was considered to be statistically significant. 

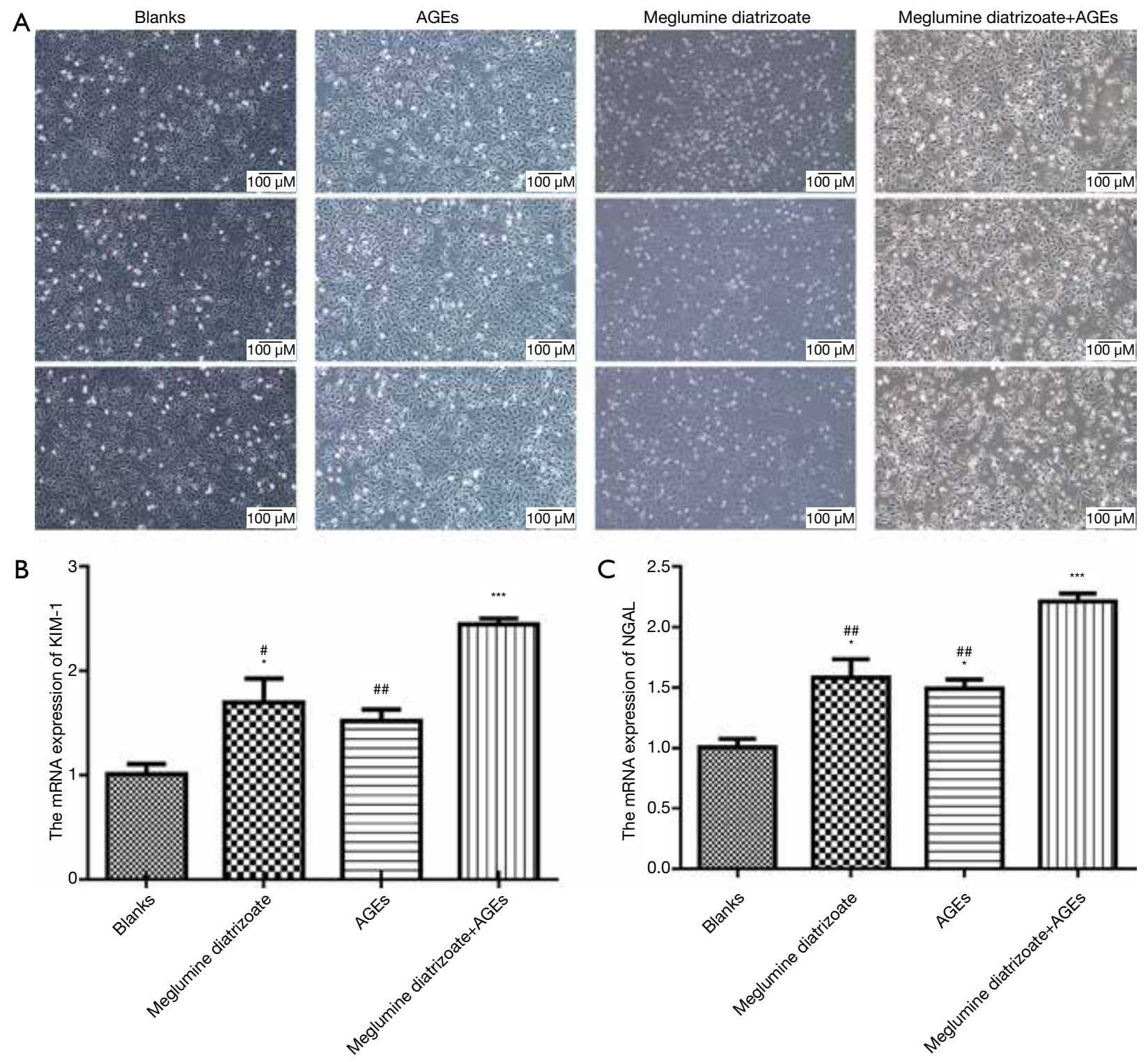

Figure 1 Meglumine diatrizoate accelerates AGEs-induced HK-2 cell damage. (A) The HK-2 cell morphology under different conditions: blank, $50 \mu \mathrm{g} / \mathrm{mL}$ AGEs, $100 \mathrm{mg} / \mathrm{mL}$ meglumine diatrizoate and $100 \mathrm{mg} / \mathrm{mL}$ meglumine diatrizoate $+50 \mu \mathrm{g} / \mathrm{mL} \mathrm{AGEs} \mathrm{(100} \mu \mathrm{m})$. The mRNA expression levels of kidney injury associated markers including KIM-1 (B) and NGAL (C) in HK-2 cells by RT-qPCR. *compared to blank group; " compared to $100 \mathrm{mg} / \mathrm{mL}$ meglumine diatrizoate $+50 \mu \mathrm{g} / \mathrm{mL}$ AGEs group. ${ }^{*} \mathrm{P}<0.05,{ }^{* * *} \mathrm{P}<0.001,{ }^{\#} \mathrm{P}<0.05$, ${ }^{\# \#} \mathrm{P}<0.01$.

\section{Results}

\section{Meglumine diatrizoate accelerates AGEs-induced HK-2 cell damage}

To observe the effects of meglumine diatrizoate and AGEs co-treated HK-2 cells, HK-2 cells were divided into four groups: blank, $50 \mu \mathrm{g} / \mathrm{mL}$ AGEs, $100 \mathrm{mg} / \mathrm{mL}$ meglumine diatrizoate and $100 \mathrm{mg} / \mathrm{mL}$ meglumine diatrizoate +
$50 \mu \mathrm{g} / \mathrm{mL}$ AGEs. After $48 \mathrm{~h}$ of treatment, the morphological changes of HK-2 cells were observed. The results showed that HK-2 cells were round or elliptical and appeared in an expanded spindle shape in the blank group (Figure 1A). However, after HK-2 cells treated with $100 \mathrm{mg} / \mathrm{mL}$ meglumine diatrizoate, $50 \mu \mathrm{g} / \mathrm{mL}$ AGEs, particularly $100 \mathrm{mg} / \mathrm{mL}$ meglumine diatrizoate $+50 \mu \mathrm{g} / \mathrm{mL}$ AGEs, the cell morphology significantly changed. We found the cells 
swelled, the membrane ruptured and fell off, the cytoplasm foamed and the nucleus condensed. In addition, the cell density was significantly reduced. Thus, combination of meglumine diatrizoate and AGEs significantly disrupted HK-2 cell morphology. KIM-1 and NGAL have been found to be markers for monitoring kidney injury in vitro. In this study, the mRNA expression levels of KIM-1 and NGAL were examined in HK-2 cells by RT-qPCR. The results showed that meglumine diatrizoate and AGEs significantly increased the mRNA expression levels of KIM1 and NGAL in HK-2 cells compared with the blank group (Figure 1B,C). Interestingly, KIM-1 and NGAL had the highest mRNA expression levels in $100 \mathrm{mg} / \mathrm{mL}$ meglumine diatrizoate $+50 \mu \mathrm{g} / \mathrm{mL}$ AGEs. Above results indicate that meglumine diatrizoate accelerates AGEs-induced HK-2 cell damage.

\section{Meglumine diatrizoate accelerates AGEs-induced HK-2 cell apoptosis}

CCK-8 assay was used to determine HK-2 cell viability. As shown in Figure 2A, compared with the blank group, the cell viability of $\mathrm{HK}-2$ cells was significantly decreased after 48 or $72 \mathrm{~h}$ of treatment with $50 \mu \mathrm{g} / \mathrm{mL}$ AGEs, $100 \mathrm{mg} / \mathrm{mL}$ meglumine diatrizoate, particularly $100 \mathrm{mg} / \mathrm{mL}$ meglumine diatrizoate $+50 \mu \mathrm{g} / \mathrm{mL}$ AGEs. Therefore, meglumine diatrizoate could inhibit AGEs-induced HK-2 cell viability. We further examined the cell apoptosis by flow cytometry. Compared to the blank group, $100 \mathrm{mg} / \mathrm{mL}$ meglumine diatrizoate group, $50 \mu \mathrm{g} / \mathrm{mL}$ AGEs group and $100 \mathrm{mg} / \mathrm{mL}$ meglumine diatrizoate $+50 \mu \mathrm{g} / \mathrm{mL}$ AGEs group significantly promoted apoptosis of HK-2 cells (Figure $2 B)$. We noticed the highest apoptosis rate of HK-2 cells in the $100 \mathrm{mg} / \mathrm{mL}$ diatrizoate $+50 \mu \mathrm{g} / \mathrm{mL}$ AGEs group. Furthermore, western blot analysis results showed that $100 \mathrm{mg} / \mathrm{mL}$ meglumine diatrizoate group, $50 \mu \mathrm{g} / \mathrm{mL}$ AGEs group, especially $100 \mathrm{mg} / \mathrm{mL}$ meglumine diatrizoate + $50 \mu \mathrm{g} / \mathrm{mL}$ AGEs group significantly promoted the expression of apoptosis marker caspase3 (Figure 2C). These results suggest that meglumine diatrizoate accelerates AGEs-induced HK-2 cell apoptosis.

\section{Meglumine diatrizoate elevates the expression levels of PKC 22 and autophagy associated markers in AGEs- induced $\mathrm{HK}-2$ cells}

We further investigated the effect of meglumine diatrizoate on PKC $\beta 2$ and $p-P K C \beta 2$ expression in AGEs-induced
HK-2 cells. Compared with the blank group, we found that $\mathrm{PKC} \beta 2$ and $\mathrm{p}-\mathrm{PKC} \beta 2$ were significantly increased in $100 \mathrm{mg} / \mathrm{mL}$ meglumine diatrizoate $+50 \mu \mathrm{g} / \mathrm{mL}$ AGEs group (Figure 2C), indicating that meglumine diatrizoate might up-regulate the expression levels of PKC $\beta 2$ and p-РКC $\beta 2$ in AGEs-induced HK-2 cells. Furthermore, we detected the expression levels of autophagy associated markers including Beclin-1, LC3 and P62 in HK-2 cells. The results showed that meglumine diatrizoate and AGEs increased the protein expression level of Beclin-1 and the ratio of LC3 II/LC3 I in HK-2 cells, especially in $100 \mathrm{mg} / \mathrm{mL}$ meglumine diatrizoate $+50 \mu \mathrm{g} / \mathrm{mL}$ AGEs group (Figure 2C) . Meanwhile, meglumine diatrizoate and AGEs significantly decreased the expression level of p62 in HK-2 cells. These results indicate that meglumine diatrizoate might induce autophagy in AGEs-induced HK-2 cells.

\section{PKCß2 knockdown alleviates meglumine diatrizoate and AGEs-induced HK-2 cell damage}

We designed three pairs of PKC $\beta 2$-siRNAs. As shown in Figure $3 A$, three pairs of PKC $\beta 2$-siRNAs significantly reduced the mRNA expression levels of $\mathrm{PKC} \beta 2$. PKC $\beta 2$ siRNA-3 had the lowest mRNA expression level of PKC $\beta 2$ in HK-2 cells. Therefore, PKC $\beta 2$-siRNA-3 was used to knock out PKC $\beta 2$ for further analysis. We observed the morphological changes of HK-2 cells under different treatment conditions. In Figure 3B, the HK-2 cells in the blank group were round or elliptical. After stimulation with AGEs + meglumine diatrizoate + PKC $\beta 2$ scramble siRNA, HK-2 cells were stretched into a fusiform or irregularly shaped structure. Furthermore, the intercellular connections were loose and arranged in parallel stripes. PKC $\beta 2$ knockdown significantly alleviated the morphological changes of HK-2 cells induced by AGEs + meglumine diatrizoate. We also observed the mRNA expression levels of kidney injury related proteins including KIM-1 and NGAL by RT-qPCR. We found that the mRNA expression of $\mathrm{PKC} 32$ was increased in meglumine diatrizoate and AGEs-induced HK-2 cells (Figure 3C). Meglumine diatrizoate promoted the mRNA expression levels of KIM1 (Figure 3D) and NGAL (Figure 3E) in AGEs-induced HK-2 cells. However, after silencing PKC $\beta 2$, the mRNA expression of KIM-1 and NGAL was significantly decreased in meglumine diatrizoate and AGEs-induced HK-2 cells. Above results reveal that $\mathrm{PKC} \beta 2$ knockdown alleviates meglumine diatrizoate and AGEs-induced HK-2 cell damage. 
A

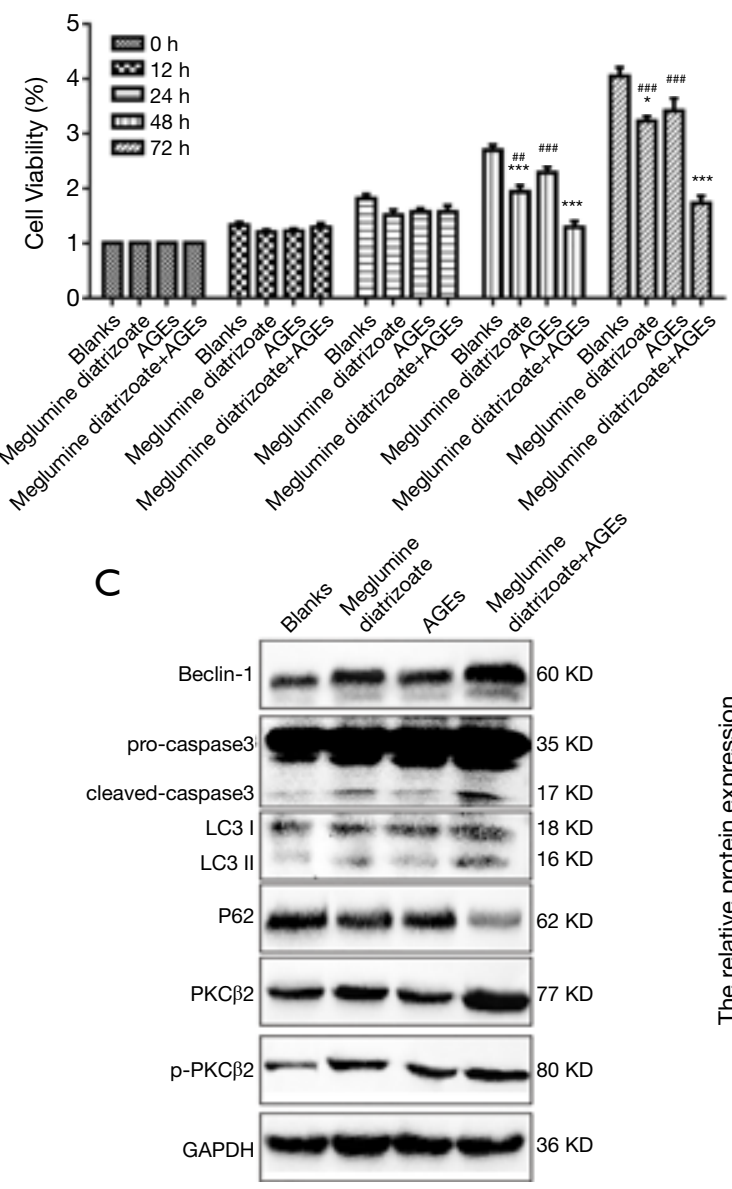

B

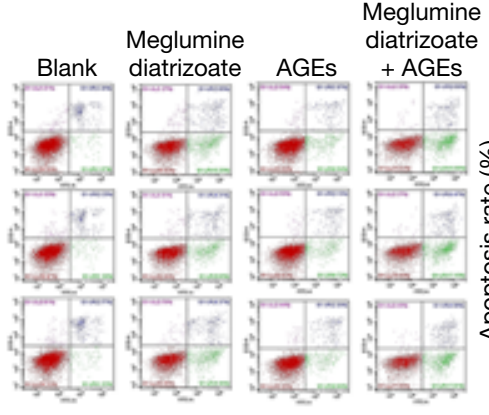

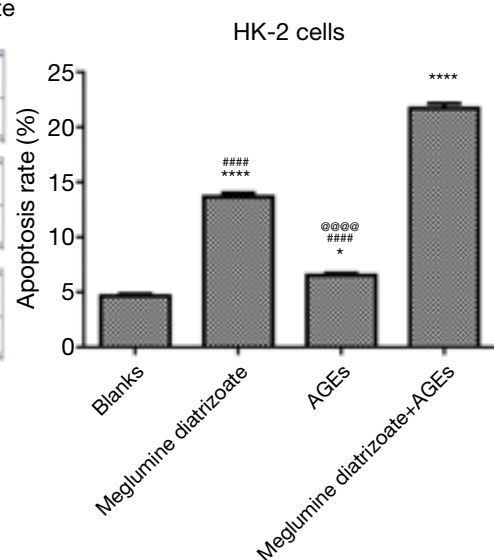

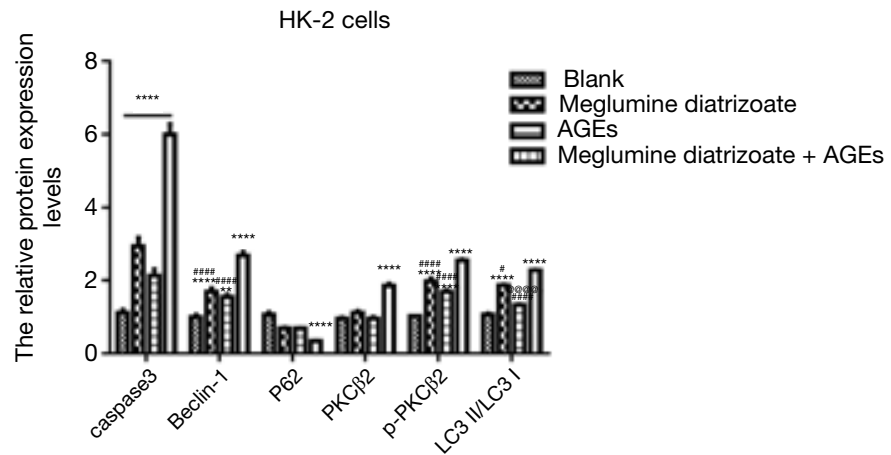

Figure 2 Meglumine diatrizoate accelerates AGEs-induced HK-2 cell apoptosis. (A) The cell viability of HK-2 cells using CCK-8 assay. (B) The apoptosis of HK-2 cells by flow cytometry. (C) Western blot showing the expression levels of apoptosis associated markers including caspase3, PKC 32 , p-PKC 32 , autophagy associated markers including Beclin-1, LC3 and P62 in HK-2 cells. *compared to the blank group; ${ }^{\#}$ compared to $100 \mathrm{mg} / \mathrm{mL}$ meglumine diatrizoate $+50 \mu \mathrm{g} / \mathrm{mL}$ AGEs; ${ }^{\oplus}$ compared to $100 \mathrm{mg} / \mathrm{mL}$ meglumine diatrizoate. ${ }^{*} \mathrm{P}<0.05,{ }^{* *} \mathrm{P}<0.01$,

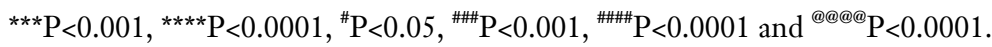

\section{PKCß2 knockdown alleviates meglumine diatrizoate and AGEs-induced HK-2 cell apoptosis}

We further investigated whether PKC $\beta 2$ knockdown could alleviate meglumine diatrizoate and AGEs-induced HK-2 cell apoptosis. Flow cytometry results showed that compared with the AGEs + meglumine diatrizoate + scramble siRNA group, the apoptosis rate of HK-2 cells was significantly decreased in the presence of siPKC $\beta 2$ in meglumine diatrizoate and AGEs-induced HK-2 cells (Figure 4A). To further evaluate the apoptosis of HK-2 cells, the expression levels of Caspase3, Bcl-2 and Bax were detected by western blot (Figure 4B). The results suggested that meglumine diatrizoate caused a significant increase in the expression of apoptosis markers including Caspase 3 and Bax in AGEs-induced HK-2 cells, while the expression of apoptosis inhibitor Bcl-2 was decreased. Furthermore, we found that inhibition of $\mathrm{PKC} \beta 2$ reversed the expression levels of Caspase 3, Bax and $\mathrm{Bcl}-2$ in meglumine diatrizoate and AGEs-induced HK-2 cells. These results reveal that PKC $\beta 2$ knockdown alleviates meglumine diatrizoate and AGEs-induced HK-2 cell apoptosis.

\section{PKC/2 knockdown weakens ERK/fNK/p38 pathway activation in meglumine diatrizoate and AGEs-induced HK-2 cells}

Our previous study has found that ERK/JNK/p38 pathway 


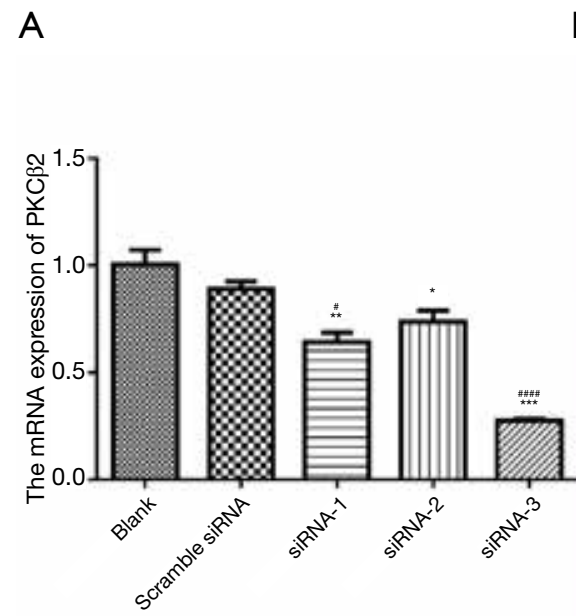

B
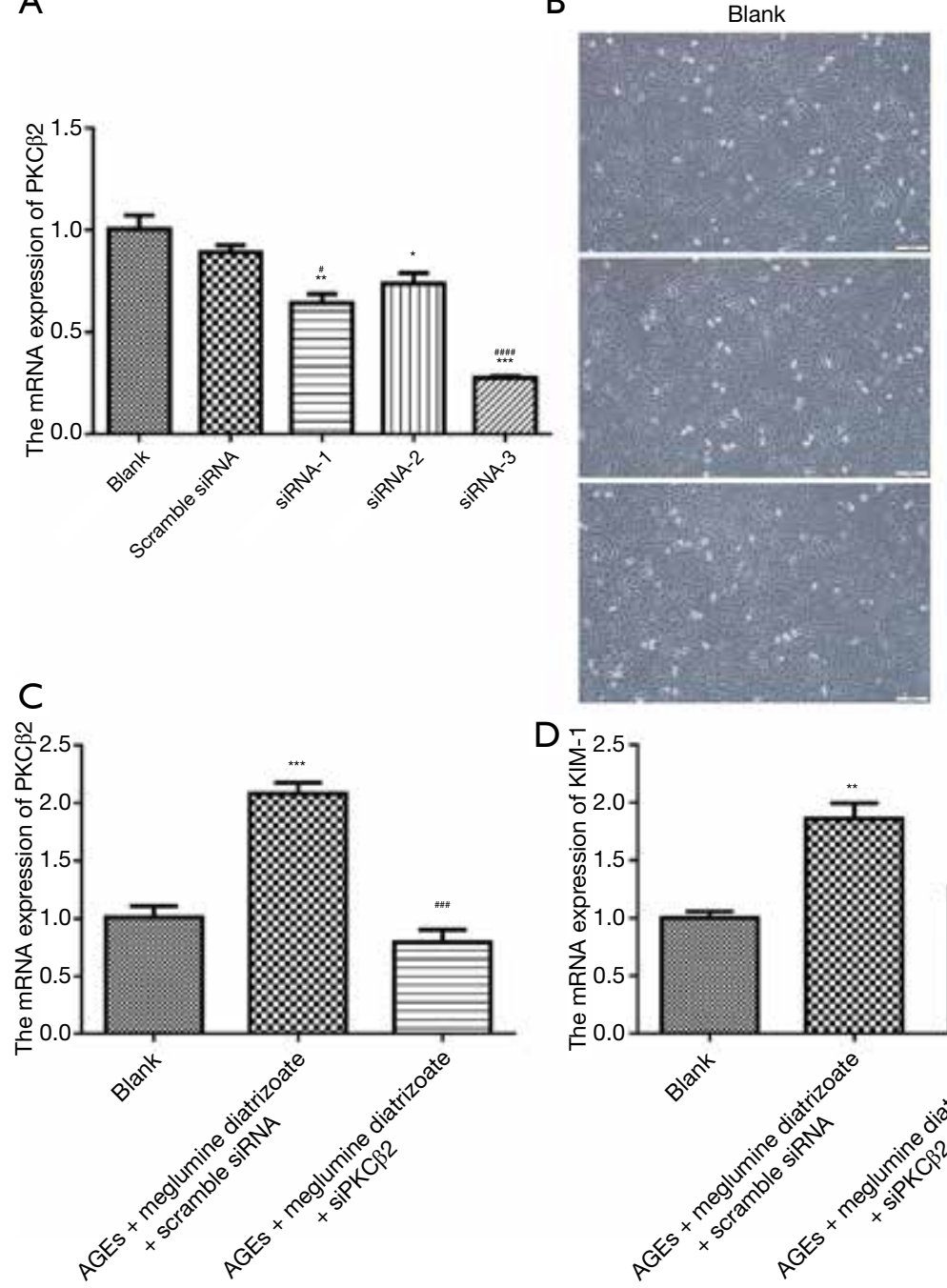

AGEs + meglumine diatrizoate + scramble siRNA
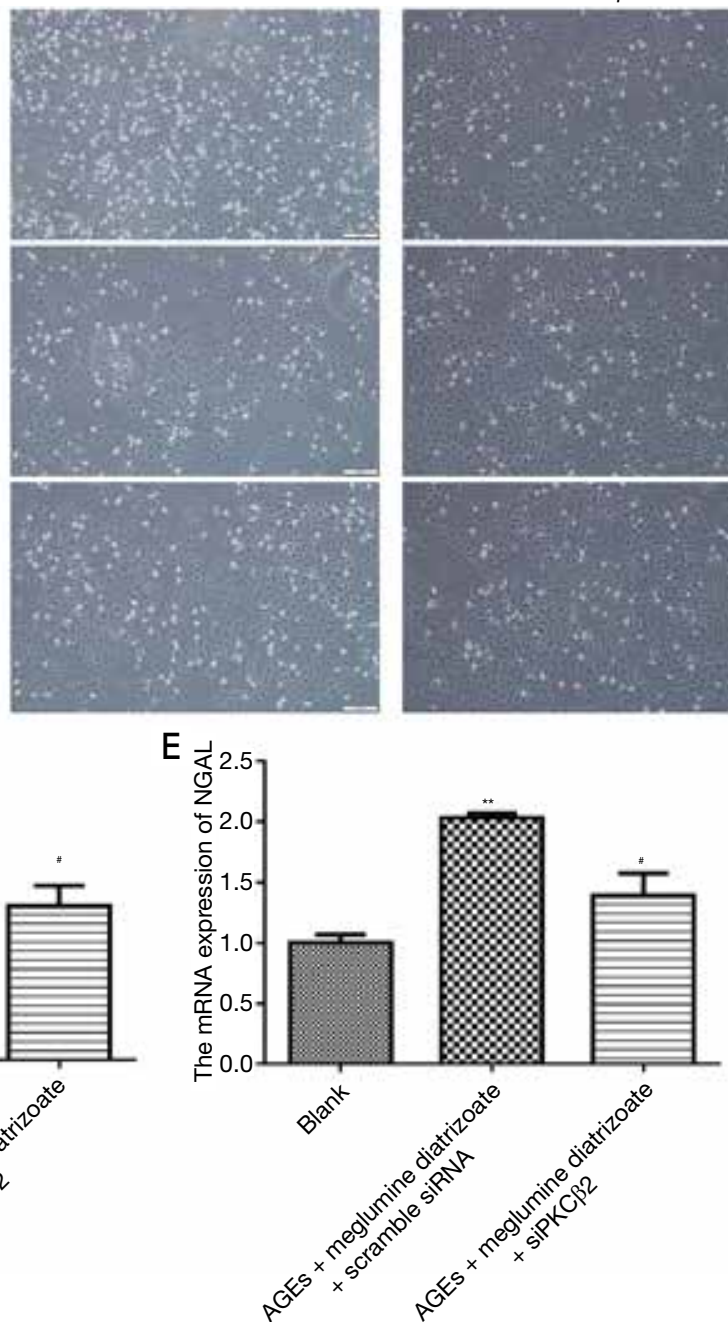

Figure 3 PKC $\beta 2$ knockdown alleviates meglumine diatrizoate and AGEs-induced HK-2 cell damage. (A) RT-qPCR assay showing the knockdown effects of 3 pairs of PKC $\beta 2$-siRNAs. * compared to the blank group; ${ }^{*}$ compared to scramble siRNA group. (B) The HK-2 cell morphology under different conditions: blank, $50 \mu \mathrm{g} / \mathrm{mL}$ AGEs $+100 \mathrm{mg} / \mathrm{mL}$ meglumine diatrizoate + PKC 2 scramble siRNA and 100 $\mathrm{mg} / \mathrm{mL}$ meglumine diatrizoate $+50 \mu \mathrm{g} / \mathrm{mL}$ AGEs + siPKC $22(100 \mu \mathrm{m})$. RT-qPCR assay showing the mRNA expression levels of PKC $\beta 2$ (C); KIM-1 (D); NGAL (E) in HK-2 cells. *compared to the blank group; "compared to $50 \mu \mathrm{g} / \mathrm{mL}$ AGEs + $100 \mathrm{mg} / \mathrm{mL}$ meglumine diatrizoate + PKCß2 scramble siRNA. ${ }^{*} \mathrm{P}<0.05,{ }^{* *} \mathrm{P}<0.01,{ }^{* * *} \mathrm{P}<0.001,{ }^{*} \mathrm{P}<0.05,{ }^{* \# *} \mathrm{P}<0.001$.

is involved in the development of CIN in diabetic mice (18). In this study, western blot results showed that compared with the blank group, the expression levels of phosphorylated ERK, JNK and p38 were significantly increased in meglumine diatrizoate and AGEs-induced HK-2 cells, whereas the expression levels of ERK, JNK and p38 were slightly increased (Figure $4 B$ ). Compared to the AGEs + diatrizoate + scramble siRNA group, siPKC $\beta 2$ reduced the expression levels of phosphorylated ERK, JNK and p38. Therefore, PKC 32 knockdown weakens ERK/ $\mathrm{JNK} / \mathrm{p} 38$ pathway activation in meglumine diatrizoate and AGEs-induced HK-2 cells.

\section{PKC及2 knockdown accelerates autophagy in meglumine diatrizoate and AGEs-induced HK-2 cells}

Western blot analysis showed that, compared to the AGEs + diatrizoate + scramble siRNA group, siPKC $\beta 2$ significantly 
A
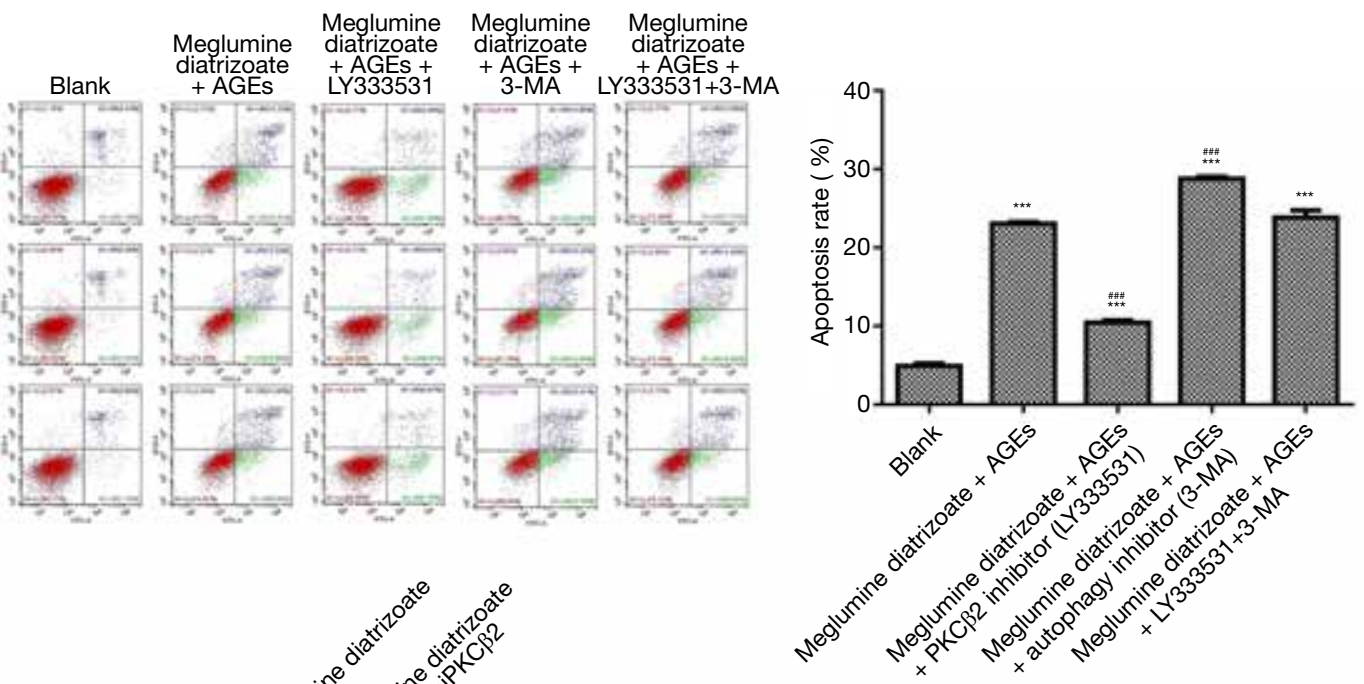

B
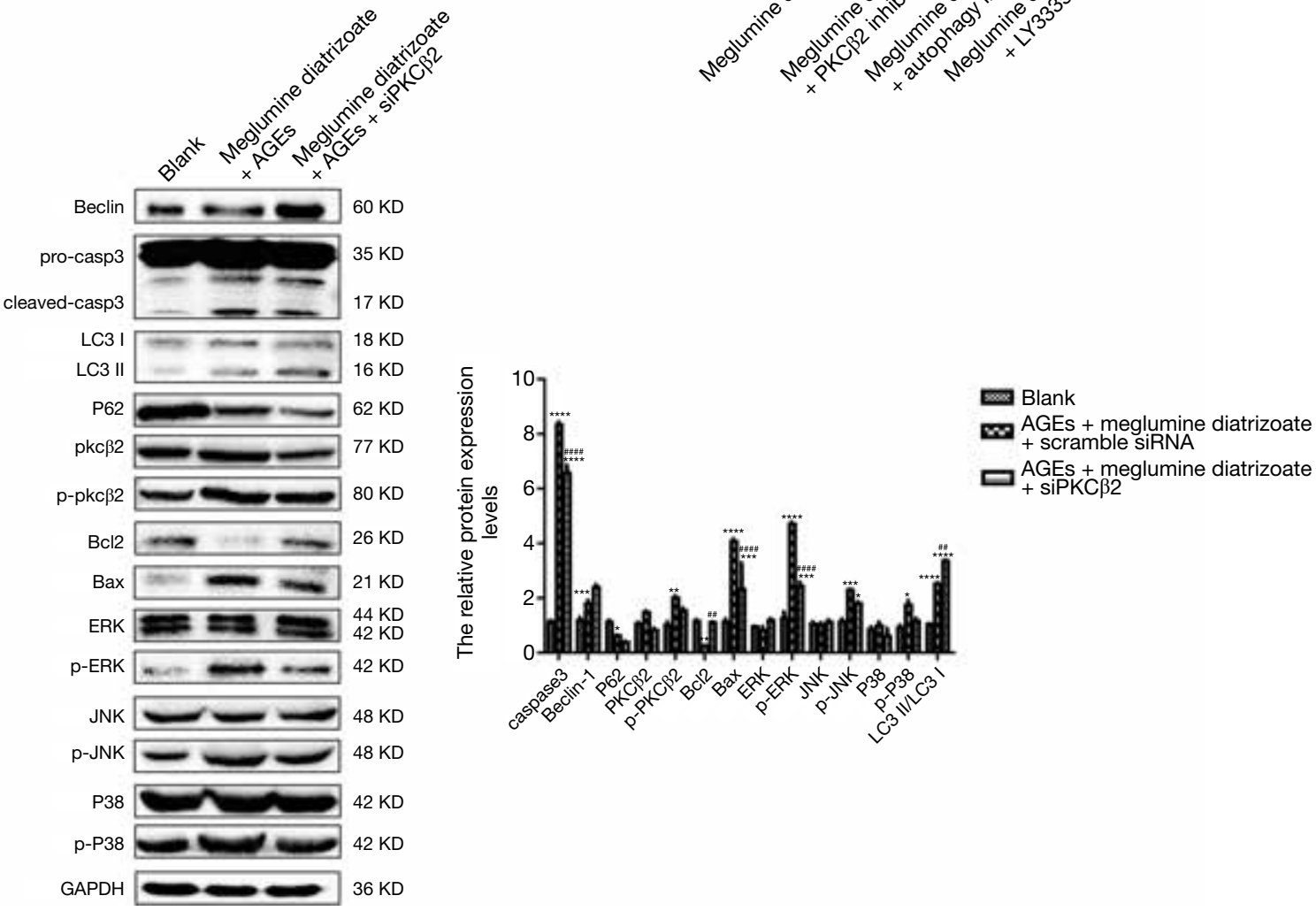

Figure 4 PKC 2 knockdown alleviates meglumine diatrizoate and AGEs-induced HK-2 cell apoptosis. (A) The apoptosis of HK-2 cells by flow cytometry assay. (B) Western blot showing the expression levels of apoptosis-related proteins, ERK/JNK/p38 pathway and autophagyrelated proteins in HK-2 cells. *compared to the blank group; "compared to AGEs + meglumine diatrizoate + scramble siRNA. ${ }^{*} \mathrm{P}<0.05$, ${ }^{* *} \mathrm{P}<0.01,{ }^{* * *} \mathrm{P}<0.001,{ }^{* * * *} \mathrm{P}<0.0001,{ }^{* \#} \mathrm{P}<0.01,{ }^{* \# *} \mathrm{P}<0.001$ and ${ }^{\# \# \#+} \mathrm{P}<0.0001$

increased the expression level of Beclin-1 and the ratio of LC3 II/LC3 I, however, the expression level of p62 was decreased (Figure $4 B$ ). These results indicate that inhibition of PKC $\beta 2$ could promote autophagy in meglumine diatrizoate and AGEs-induced HK-2 cells.

To determine the optimal concentration of PKC $\beta 2$ inhibitor LY333531, CCK-8 was used to detect the cell viability of HK-2 cells under different concentrations of LY333531. The results showed that LY333531 inhibited the cell viability of HK-2 cells in a concentration-dependent manner (Figure 5A). Western blot was used to detect the expression of PKC $\beta 2$ under different concentrations of LY333531. We found that LY333531 suppressed the expression level of $\mathrm{PKC} \beta 2$ in a concentration-dependent 

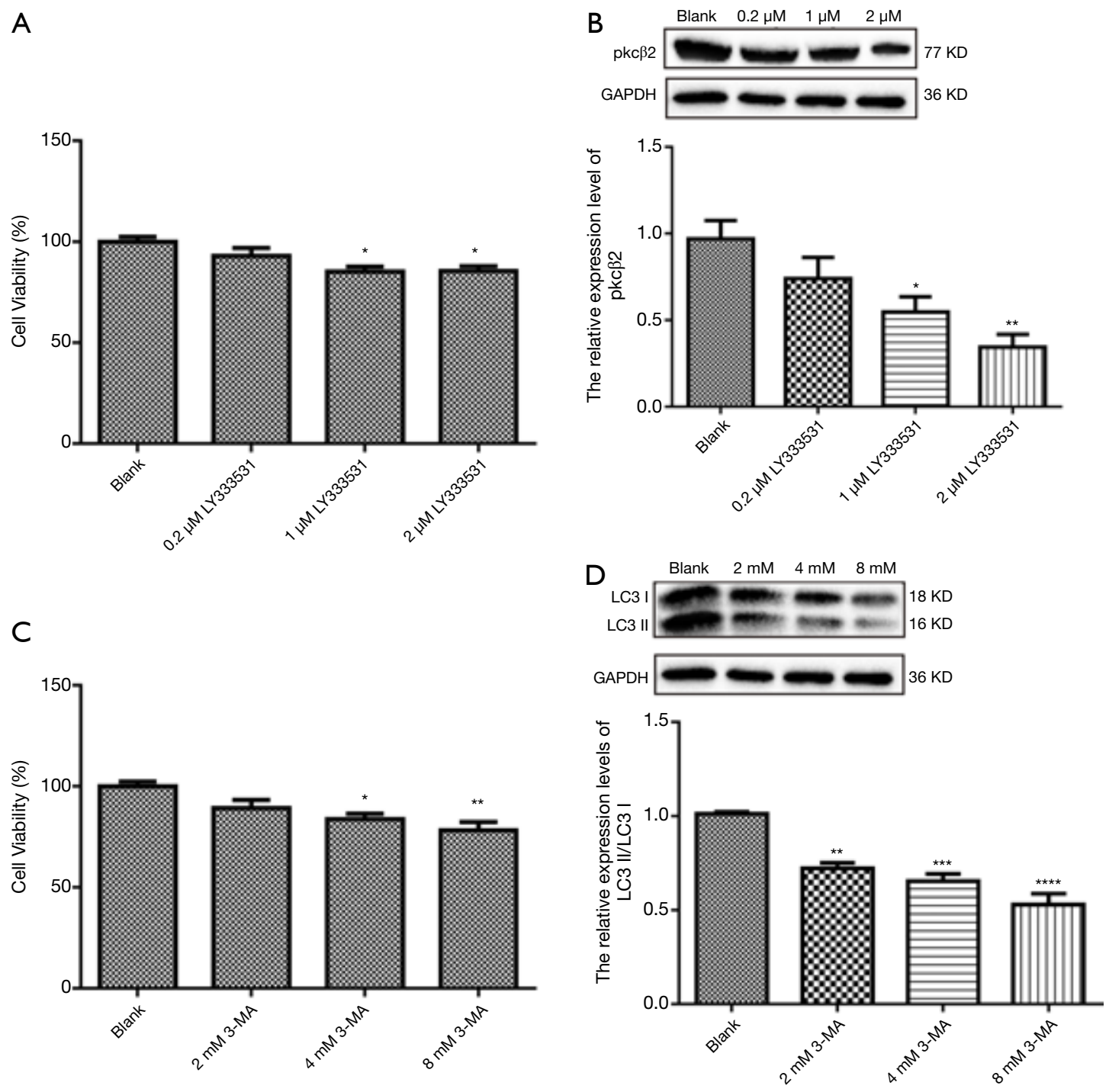

Figure 5 PKC $\beta 2$ knockdown accelerates autophagy in meglumine diatrizoate and AGEs-induced HK-2 cells. (A) CCK-8 assay showing the cell viability of HK-2 cells under different concentrations of LY333531. (B) Western blot showing the expression of PKC $\beta 2$ under different concentrations of LY333531. (C) The cell viability of HK-2 cells under different concentrations of 3-MA using CCK-8 assay. (D) The ratio of LC3 II/LC3 I at different concentrations of 3-MA by western blot. ${ }^{*}$ compared to the blank group; ${ }^{*} \mathrm{P}<0.05,{ }^{* *} \mathrm{P}<0.01,{ }^{* * *} \mathrm{P}<0.001$ and **** $\mathrm{P}<0.0001$.

manner (Figure 5B). $2 \mu \mathrm{M}$ of LY333531 was identified for further experiments.

To determine the optimal concentration of the autophagy inhibitor 3-MA, CCK-8 was used to detect the cell viability of HK-2 cells at various concentrations of 3-MA. We found that 3-MA inhibited the cell viability of HK-2 cells in a concentration-dependent manner (Figure 5C). As shown in western blot results, the ratio of LC3 II/LC3 I at different concentrations of 3-MA. We found that 3-MA reduced the ratio of LC3 II/LC3 I was significantly decreased in a concentration-dependent manner (Figure 5D). LC3 II/LC3 I had the lowest ratio in HK-2 cells treated with $8 \mathrm{mM} 3-\mathrm{MA}$.

PKCB2 inbibitor LY333531 reverses 3-MA-induced autophagy inbibition in meglumine diatrizoate and AGEsinduced $\mathrm{HK}-2$ cells

After determining the optimal concentration of PKC $\beta 2$ 
A
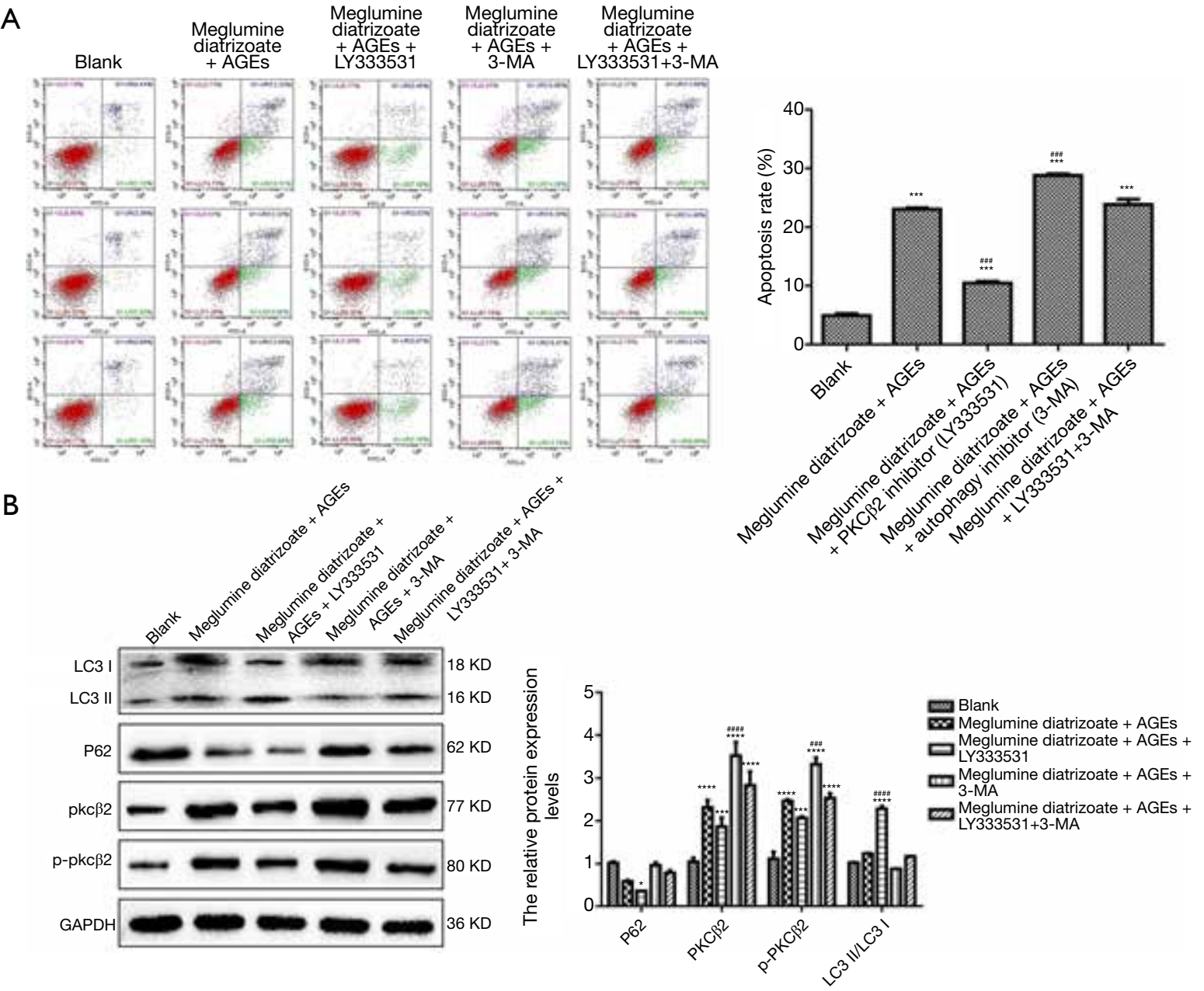

Figure 6 PKC 32 inhibitor LY333531 reverses 3-MA-induced autophagy inhibition in meglumine diatrizoate and AGEs-induced HK-2 cells. (A) The apoptosis of HK-2 cells by flow cytometry assay. (B) Western blot results showing the expression levels of PKC $\beta 2$, p-PKC $\beta 2$, autophagy related proteins including LC3 II/LC3 I and p62 in HK-2 cells. *compared to the blank group; " compared to meglumine diatrizoate + AGEs group. ${ }^{*} \mathrm{P}<0.05,{ }^{* * *} \mathrm{P}<0.001,{ }^{* * * *} \mathrm{P}<0.0001,{ }^{\# \# !} \mathrm{P}<0.001$ and ${ }^{\# \# ! *} \mathrm{P}<0.0001$.

inhibitor LY333531 and autophagy inhibitor 3-MA, HK-2 cells were divided into five groups, as follows: blank group; meglumine diatrizoate + AGEs group; meglumine diatrizoate + AGEs + PKC 32 inhibitor LY333531 group; meglumine diatrizoate + AGEs + autophagy inhibitor 3-MA group; meglumine diatrizoate + AGEs + PKC $\beta 2$ inhibitor LY333531 + autophagy inhibitor 3-MA group. As shown in Figures $6 A$, in meglumine diatrizoate + AGEs group, РКC $\beta 2$ inhibitor LY333531 significantly inhibited cell apoptosis in meglumine diatrizoate and AGEs-induced HK-2 cells. In the meglumine diatrizoate + AGEs + PKC $\beta 2$ inhibitor LY333531 + autophagy inhibitor 3-MA group, the apoptosis of HK-2 cells was significantly increased compared with the meglumine diatrizoate + AGEs group. Furthermore, we found that autophagy inhibitor 3-MA reversed LY333531induced apoptosis inhibition in meglumine diatrizoate and AGEs-induced HK-2 cells. These results reveal that PKC 32 inhibitor LY333531 could ameliorate the apoptosis of meglumine diatrizoate and AGEs-induced HK-2 cells. However, autophagy inhibitor 3-MA could aggravate meglumine diatrizoate and AGEs-induced HK-2 cell apoptosis.

We further examined the expression of PKC $\beta 2$, phosphorylated $\mathrm{PKC} \beta 2$ and autophagy-related proteins by western blot. We found that PKC $\beta 2$ and phosphorylated $\mathrm{PKC} \beta 2$ had the highest expression levels in meglumine 
diatrizoate + AGEs + autophagy inhibitor 3-MA group (Figure 6B). Compared with the diatrizoate + AGEs group, PKC $\beta 2$ inhibitor LY333531 inhibited the expression levels of $\mathrm{PKC} \beta 2$ and phosphorylated $\mathrm{PKC} \beta 2$ were inhibited in meglumine diatrizoate and AGEs-induced HK-2 cells. Compared with the meglumine diatrizoate + AGEs + PKC $\beta 2$ inhibitor LY333531 group, autophagy inhibitor 3-MA increased the expression levels of $\mathrm{PKC} \beta 2$ and phosphorylated PKC $\beta 2$. These results suggest that autophagy inhibitor 3-MA could alleviate $\mathrm{PKC} \beta 2$ inhibitor LY333531-induced PKC $\beta 2$ and phosphorylated PKC $\beta 2$ inhibition in meglumine diatrizoate and AGEs-induced HK-2 cells.

As shown in Figure 6B, we found that in the meglumine diatrizoate + AGEs + PKC $\beta 2$ inhibitor LY333531 group, the ratio of LC3 II/LC3 I was the highest and the expression of p62 was the lowest in HK-2 cells, suggesting that PKC $\beta 2$ inhibitor LY33353 could promote autophagy in meglumine diatrizoate and AGEs-induced HK-2 cells. Compared with the meglumine diatrizoate + AGEs + autophagy inhibitor 3-MA group, PKC 32 inhibitor LY333531 increased the ratio of LC3 II/LC3 I and decreased the expression of p62. These results show that PKC $\beta 2$ inhibitor LY333531 could reverse autophagy inhibitor 3-MA-induced autophagy inhibition in meglumine diatrizoate and AGEs-induced HK-2 cells.

To further analyze the effects of PKC $\beta 2$ inhibitor on the formation of autophagy in meglumine diatrizoate and AGEs-induced HK-2 cells, we observed the expression of autophagy-specific protein LC3 under fluorescence confocal microscopy, as shown in Figure 7. LC3 is a representative autophagosome marker that is essential for the formation of autophagosomes. During autophagy, the cytosolic form of LC3 (LC3-I) is converted to LC3II by Atg7 (E1-like enzyme) and Atg3 (E2-like enzyme). In the present study, the immunofluorescence assay results showed that the expression of LC3-II in the cytoplasm of HK-2 cells was the highest in the meglumine diatrizoate + AGEs + PKC 32 inhibitor LY333531 group. 3-MA, an inhibitor of phosphatidylinositol 3-kinase, can inhibit the onset of autophagosome formation. However, we found that compared with the diatrizoate + AGEs + autophagy inhibitor 3-MA group, PKC $\beta 2$ inhibitor LY333531 promoted the expression of LC3-II in the cytoplasm of HK-2 cells. Above results reveal that PKC $\beta 2$ inhibitor LY333531 could accelerate autophagy formation in meglumine diatrizoate and AGEs-induced HK-2 cells. Moreover, we detected autophagy in HK-2 cells under transmission electron microscopy. As shown in
Figure 8 , in the blank group, HK-2 cells showed normal cytoplasm and no autophagosome formation. However, in the meglumine diatrizoate + AGEs + PKC $\beta 2$ inhibitor LY333531 group, we observed a significant accumulation of autophagosomes, encapsulating cytoplasmic material and/or membrane vesicles in vacuoles. Compared with the meglumine diatrizoate + AGEs + autophagy inhibitor 3-MA group, PKC 32 inhibitor LY333531 promoted autophagy accumulation in the cytoplasm of HK-2 cells. These results indicate that PKC $\beta 2$ inhibitor LY333531 could promote the formation of autophagy induced by meglumine diatrizoate and AGEs in HK-2 cells.

\section{Discussion}

This study analyzed the important role of PKC $\beta 2$ in apoptosis and autophagy in meglumine diatrizoate and AGEs-induced HK-2 cells. Our findings provide evidence that PKC $\beta 2$ knockdown can protect HK-2 cells against meglumine diatrizoate and AGEs-induced apoptosis and autophagy.

In our study, we observed that meglumine diatrizoate promoted morphological changes in AGEs-induced HK-2 cells. A recent study found that serum NGAL and urinary KIM-1 levels in patients with coronary stenting can reflect early changes in renal function, providing a basis for early diagnosis of CIN (20). We found that meglumine diatrizoate increased the mRNA expression levels of kidney injury markers including KIM-1 and NGAL in AGEs-induced HK-2 cells. Therefore, meglumine diatrizoate can accelerate AGEs-induced HK-2 cell damage. We also observed that meglumine diatrizoate inhibited AGEs-induced HK-2 cell viability, and promoted cell apoptosis. Consistent with previous studies, it has been found that HK-2 cell viability was inhibited after exposure to AGEs (21).

Meglumine diatrizoate elevated the expression levels of PKC $\beta 2$ and p-PKC $\beta 2$ in AGEs-induced HK-2 cells. Our previous study has reported that breviscapine could decrease the expression of p-PKC $\beta 2$ in CIN diabetic mice. Moreover, in a rat model of diabetic nephropathy, the levels of AGEs and $\mathrm{p}-\mathrm{PKC}-\beta$ were significantly increased in injured kidneys (22). Our findings suggested that PKC $\beta 2$ knockdown significantly alleviated the morphological changes of HK-2 cells induced by AGEs and meglumine diatrizoate. Silencing PKC $\beta 2$ decreased the mRNA expression levels of KIM-1 and NGAL in meglumine diatrizoate and AGEs-induced HK-2 cells. These results revealed that $\mathrm{PKC} \beta 2$ knockdown could alleviate meglumine diatrizoate and AGEs-induced HK-2 cell damage. It has 


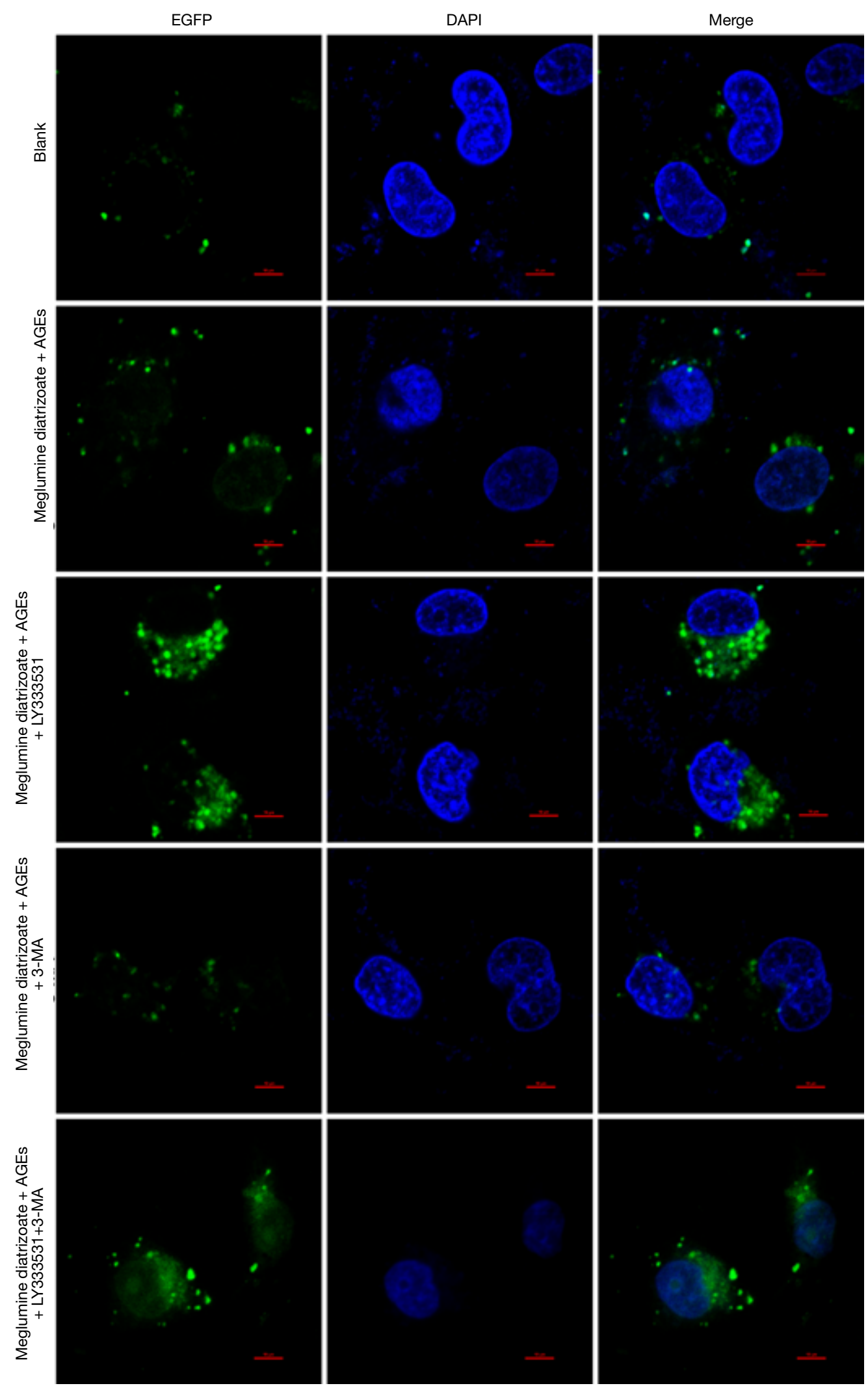

Figure 7 Immunofluorescence showing LC3-positive staining in HK-2 cells (scale bar $10 \mu \mathrm{m}$ ). 


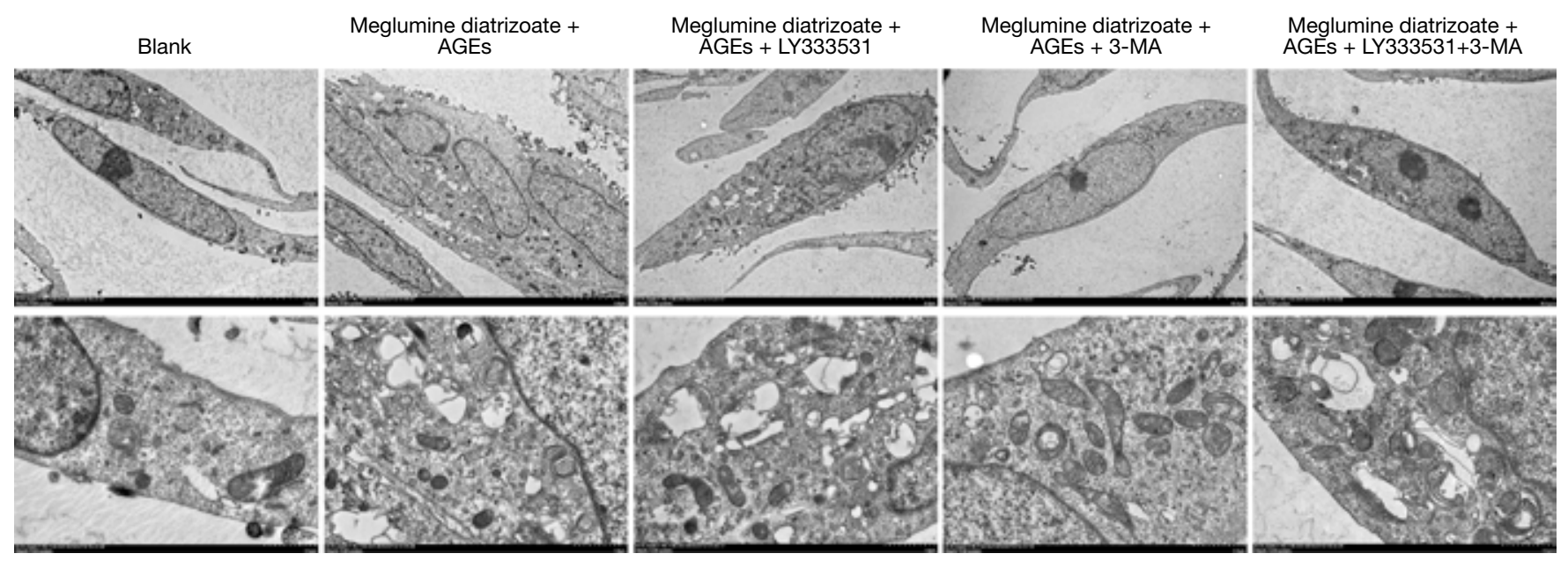

Figure 8 Transmission electron microscopy showing the autophagosome formation in HK-2 cells (scale bar $5 \mu \mathrm{m}$ ).

been confirmed that PKC- $\beta 2$ knockdown can reduce proteinuria in an animal model of diabetes. AGEs could activate PKC- $\beta 2$ in neonatal mesangial cells (23). Furthermore, we found that siPKC $\beta 2$ decreased meglumine diatrizoate and AGEs-induced HK-2 cell apoptosis. Meglumine diatrizoate up-regulated the expression of apoptosis markers including Caspase 3 and Bax in AGEsinduced HK-2 cells, while down-regulated the expression of apoptosis inhibitor Bcl-2. However, PKC $\beta 2$ knockdown reversed the expression levels of Caspase 3, Bax and Bcl2 in meglumine diatrizoate and AGEs-induced HK-2 cells. Thus, PKC $\beta 2$ knockdown could alleviate meglumine diatrizoate and AGEs-induced HK-2 cell apoptosis. In our study, meglumine diatrizoate promoted the expression levels of ERK, pERK, JNK, pJNK and p38 in AGEs-induced HK-2 cells. Intriguingly, PKC $\beta 2$ knockdown inhibited the expression levels of pERK, JNK and p38. Therefore, PKC 32 knockdown weakens ERK/JNK/p38 pathway activation in meglumine diatrizoate and AGEs-induced HK-2 cells $(24,25)$.

Autophagy is a key biological phenomenon involved in the development and growth of organisms (26). Many studies have focused much on the role of autophagy in kidney diseases $(27,28)$. Increasing evidence shows that during acute kidney injury, rapid induction of autophagy protects tubular cells from injury, while genetic defects associated with autophagy can lead to impaired renal function $(29,30)$. In our study, we found that meglumine diatrizoate up-regulated the expression of autophagy associated markers in AGEs-induced HK-2 cells. Furthermore, PKC $\beta 2$ knockdown increased the expression level of Beclin-1 and LC3 II/LC3 I ratio, while decreased the expression level of p62. After determining the optimal concentration of PKC $\beta 2$ inhibitor LY333531 $(2 \mu \mathrm{M})$ and autophagy inhibitor 3-MA $(8 \mathrm{mM})$, we found that LY333531 could ameliorate meglumine diatrizoate and AGEs-induced HK-2 cell apoptosis. Previous studies have shown that PKC $\beta$ inhibitors are effective in treating diabetes. LY333531 has been found to significantly attenuate cell apoptosis and up-regulate swiprosin-1 (a potent proapoptotic protein) in glomerular endothelial cells of diabetic mice (31). However, we found that autophagy inhibitor 3-MA could aggravate meglumine diatrizoate and AGEsinduced HK-2 cell apoptosis. Furthermore, 3-MA could alleviate PKC $\beta 2$ inhibitor LY333531-induced PKC $\beta 2$ and phosphorylated PKC $\beta 2$ inhibition in meglumine diatrizoate and AGEs-induced HK-2 cells. LY333531 increased LC3 II/LC3 I ratio in meglumine diatrizoate and AGEs-induced HK-2 cells. Moreover, LY333531 could reverse autophagy inhibitor 3-MA-induced autophagy inhibition in meglumine diatrizoate and AGEs-induced HK-2 cells. Under fluorescence confocal microscopy, we found that LY333531 promoted the expression of LC3-II in the cytoplasm of HK-2 cells induced by meglumine diatrizoate and AGEs. Similarly, PKC 32 inhibitor LY333531 could promote the formation of autophagy induced by meglumine diatrizoate and AGEsinduced HK-2 cells under transmission electron microscopy, indicating that $\mathrm{PKC} \beta 2$ could be involved in protecting renal tubular epithelial cells.

\section{Conclusions}

Taken together, our findings indicate that $\mathrm{PKC} \beta 2$ 
knockdown protects HK-2 cells against meglumine diatrizoate and AGEs-induced apoptosis and autophagy, which provides a novel insight for the treatment of CIN in diabetic patients. PKC $\beta 2$ could become a promising therapeutic tool, therefore, it is necessary to better understand the mechanism of $\mathrm{PKC} \beta 2$ in kidney protection.

\section{Acknowledgments}

Funding: This work was funded by the Natural Science Foundation of Zhejiang Province (2017C37166).

\section{Footnote}

Conflicts of Interest: The authors have no conflicts of interest to declare.

Ethical Statement: The authors are accountable for all aspects of the work in ensuring that questions related to the accuracy or integrity of any part of the work are appropriately investigated and resolved. The study was approved by The Third Clinical Institute Affiliated to Wenzhou Medical University.

Open Access Statement: This is an Open Access article distributed in accordance with the Creative Commons Attribution-NonCommercial-NoDerivs 4.0 International License (CC BY-NC-ND 4.0), which permits the noncommercial replication and distribution of the article with the strict proviso that no changes or edits are made and the original work is properly cited (including links to both the formal publication through the relevant DOI and the license). See: https://creativecommons.org/licenses/by-nc-nd/4.0/.

\section{References}

1. Barbieri L, Verdoia M, Marino P, et al. Contrast volume to creatinine clearance ratio for the prediction of contrastinduced nephropathy in patients undergoing coronary angiography or percutaneous intervention. Eur J Prev Cardiol 2016;23:931-7.

2. Joo C, Park E, Min JW, et al. Contrast Media-Induced Nephropathy in Patients with Unruptured Cerebral Aneurysm After Coiling Endovascular Treatment. World Neurosurg 2019;121:e39-44.

3. Wang Y, Wang B, Qi X, et al. Resveratrol Protects Against Post-Contrast Acute Kidney Injury in Rabbits With Diabetic Nephropathy. Front Pharmacol 2019;10:833.
4. Arellano Buendía AS, Tostado Gonzalez M, Sanchez Reyes $\mathrm{O}$, et al. Immunomodulatory Effects of the Nutraceutical Garlic Derivative Allicin in the Progression of Diabetic Nephropathy. Int J Mol Sci 2018. doi: 10.3390/ ijms19103107.

5. Mamoulakis C, Tsarouhas K, Fragkiadoulaki I, et al. Contrast-induced nephropathy: Basic concepts, pathophysiological implications and prevention strategies. Pharmacol Ther 2017;180:99-112.

6. Khaleel SA, Raslan NA, Alzokaky AA, et al. Contrast media (meglumine diatrizoate) aggravates renal inflammation, oxidative DNA damage and apoptosis in diabetic rats which is restored by sulforaphane through $\mathrm{Nrf2} / \mathrm{HO}-1$ reactivation. Chem Biol Interact 2019;309:108689.

7. Liu Y, He YT, Tan N, et al. Preprocedural N-terminal pro-brain natriuretic peptide (NT-proBNP) is similar to the Mehran contrast-induced nephropathy (CIN) score in predicting CIN following elective coronary angiography. J Am Heart Assoc 2015;4. doi: 10.1161/JAHA.114.001410.

8. Jin J, Shi Y, Gong J, et al. Exosome secreted from adiposederived stem cells attenuates diabetic nephropathy by promoting autophagy flux and inhibiting apoptosis in podocyte. Stem Cell Res Ther 2019;10:95.

9. Lin TA, Wu VC, Wang CY. Autophagy in Chronic Kidney Diseases. Cells 2019;8. doi: 10.3390/cells8010061.

10. Warren AM, Knudsen ST, Cooper ME. Diabetic nephropathy: an insight into molecular mechanisms and emerging therapies. Expert Opin Ther Targets 2019;23:579-91.

11. Lv L, Zhang J, Tian F, et al. Arbutin protects HK-2 cells against high glucose-induced apoptosis and autophagy by up-regulating microRNA-27a. Artif Cells Nanomed Biotechnol 2019;47:2940-7.

12. Kim EM, Jung CH, Kim J, et al. The p53/p21 Complex Regulates Cancer Cell Invasion and Apoptosis by Targeting Bcl-2 Family Proteins. Cancer Res 2017;77:3092-100.

13. Rogers C, Fernandes-Alnemri T, Mayes L, et al. Cleavage of DFNA5 by caspase-3 during apoptosis mediates progression to secondary necrotic/pyroptotic cell death. Nat Commun 2017;8:14128.

14. Alghamdi TA, Majumder S, Thieme K, et al. Janus Kinase 2 Regulates Transcription Factor EB Expression and Autophagy Completion in Glomerular Podocytes. J Am Soc Nephrol 2017;28:2641-53.

15. Hamurcu Z, Delibasi N, Gecene S, et al. Targeting LC3 and Beclin-1 autophagy genes suppresses proliferation, survival, migration and invasion by inhibition of Cyclin-D1 and uPAR/Integrin beta1/Src signaling in 
triple negative breast cancer cells. J Cancer Res Clin Oncol 2018;144:415-30.

16. Xiang J, Jiang T, Zhang W, et al. Human umbilical cordderived mesenchymal stem cells enhanced HK-2 cell autophagy through MicroRNA-145 by inhibiting the PI3K/AKT/mTOR signaling pathway. Exp Cell Res 2019;378:198-205.

17. Faria A, Persaud SJ. Cardiac oxidative stress in diabetes: Mechanisms and therapeutic potential. Pharmacol Ther 2017;172:50-62.

18. Jiang $W$, Li Z, Zhao $W$, et al. Breviscapine attenuatted contrast medium-induced nephropathy via PKC/Akt/ MAPK signalling in diabetic mice. Am J Transl Res 2016;8:329-41.

19. Ryan MJ, Johnson G, Kirk J, et al. HK-2: an immortalized proximal tubule epithelial cell line from normal adult human kidney. Kidney Int 1994;45:48-57.

20. Liao B, Nian W, Xi A, et al. Evaluation of a Diagnostic Test of Serum Neutrophil Gelatinase-Associated Lipocalin (NGAL) and Urine KIM-1 in Contrast-Induced Nephropathy (CIN). Med Sci Monit 2019;25:565-70.

21. Zhao Y, Zhang W, Jia Q, et al. High Dose Vitamin E Attenuates Diabetic Nephropathy via Alleviation of Autophagic Stress. Front Physiol 2019;9:1939.

22. Qiu YY, Tang LQ, Wei W. Berberine exerts renoprotective effects by regulating the AGEs-RAGE signaling pathway in mesangial cells during diabetic nephropathy. Mol Cell Endocrinol 2017;443:89-105.

23. Scivittaro V, Ganz MB, Weiss MF. AGEs induce oxidative stress and activate protein kinase C-beta(II)

Cite this article as: Jiang W, Zhao W, Ye F, Huang S, Wu Y, Chen H, Zhou R, Fu G. Inhibiting PKC $\beta 2$ protects HK-2 cells against meglumine diatrizoate and AGEs-induced apoptosis and autophagy. Ann Transl Med 2020;8(6):293. doi: 10.21037/ atm.2020.02.172 in neonatal mesangial cells. Am J Physiol Renal Physiol 2000;278:F676-83.

24. Li X, Ma J, Shi W, et al. Calcium Oxalate Induces Renal Injury through Calcium-Sensing Receptor. Oxid Med Cell Longev 2016;2016:5203801.

25. Shen H, Fang K, Guo H, et al. High Glucose-Induced Apoptosis in Human Kidney Cells Was Alleviated by miR15b-5p Mimics. Biol Pharm Bull 2019;42:758-63.

26. Parodi C, Hardman JA, Allavena G, et al. Autophagy is essential for maintaining the growth of a human (mini-) organ: Evidence from scalp hair follicle organ culture. PLoS Biol 2018;16:e2002864.

27. Bork T, Liang $W$, Yamahara K, et al. Podocytes maintain high basal levels of autophagy independent of mtor signaling. Autophagy 2019:1-17. [Epub ahead of print].

28. Ye X, Zhou XJ, Zhang H. Autophagy in Immune-Related Renal Disease. J Immunol Res 2019;2019:5071687.

29. Lanning NJ, VanOpstall C, Goodall ML, et al. LRRK2 deficiency impairs trans-Golgi to lysosome trafficking and endocytic cargo degradation in human renal proximal tubule epithelial cells. American journal of physiology. Am J Physiol Renal Physiol 2018;315:F1465-77.

30. Wang Y, Tang C, Cai J, et al. PINK1/Parkin-mediated mitophagy is activated in cisplatin nephrotoxicity to protect against kidney injury. Cell Death Dis 2018;9:1113.

31. Wang ZB, Zhang S, Li Y, et al. LY333531, a PKCbeta inhibitor, attenuates glomerular endothelial cell apoptosis in the early stage of mouse diabetic nephropathy via down-regulating swiprosin-1. Acta Pharmacol Sin 2017;38:1009-23. 